\title{
Permits For Cash: A Fair and Equitable Resolution to the Public Land Range War
}

\author{
MARK SALVO AND ANDY KERR
}

$\mathrm{S}$ Since 1998 an increasing number of conservation organizations have advocated for federal legislation to authorize and fund a program to allow livestock operators to relinquish their federal grazing permits back to the government for compensation. The legislation would require the managing agencies to permanently retire the permits, reallocating forage to wildlife and allowing associated allotments to recover from domestic livestock grazing. Compensation paid to operators would be based on the fair market value of each permit. Operators who participate in the program would still own their base properties, and could use their payments to restructure their ranch (including purchase more private grazing land) or retire ${ }^{1}$.

As envisioned here, permanent permit retirement is prohibited under current law which effectively requires Bureau of Land Management and Forest Service managers to transfer grazing permits to new graziers upon the resignation or retirement of the previous permittee. (Permits are cancelled without permittee consent in rare cases where the associated allotment has been severely overgrazed, it is court ordered, or Congress so directs, such as within a national park). However, there are numerous examples where conservation organizations, livestock operators, and federal proprietors have creatively worked within the bounds of current law to retire permits. In some cases Congress has also passed legislation to allow for permit retirement on specially designated land. These examples have been enormously successful and support the

${ }^{1}$ Andy Kerr, "The Voluntary Retirement Option for Federal Public Lands Grazing Permittees," Rangelands 20(5) (1998): 26-29 (simultaneously published in Wild Earth 8(3) (1998) 63-67).

${ }^{2} 16$ U.S.C. $\$ 410 \mathrm{~mm}-1(\mathrm{f})(2)$. need for a much broader, federally financed program. They have demonstrated permit retirement as a socially compassionate, policy efficient, politically expedient, and ecologically responsible way to end livestock grazing on public land.

The following examples represent a wide variety of purposes for permit retirement and the numerous agencies and private parties that have been involved. The price per acre or animal unit month (AUM) has varied depending on the location, the payor, and other circumstances. Retiring the permit was voluntary in every case, and respect and cooperation between the permittee, government agencies, conservationists, and legislators was the key to completing each transaction. Great Basin National Park, Nevada - In 1996, under the leadership of Senator Harry Reid (D-NV), and with the support of the entire Nevada delegation (two Republicans, two Democrats), Congress amended the law that established Great Basin National Park to allow permittees to donate their grazing permits for allotments inside the park back to the Park Service. ${ }^{2}$ In 1999 three permittees agreed to relinquish their permits for cattle grazing in the park and part of the adjacent Mt. Moriah Wilderness

\section{Federal Grazing Permit Retirement in the West}

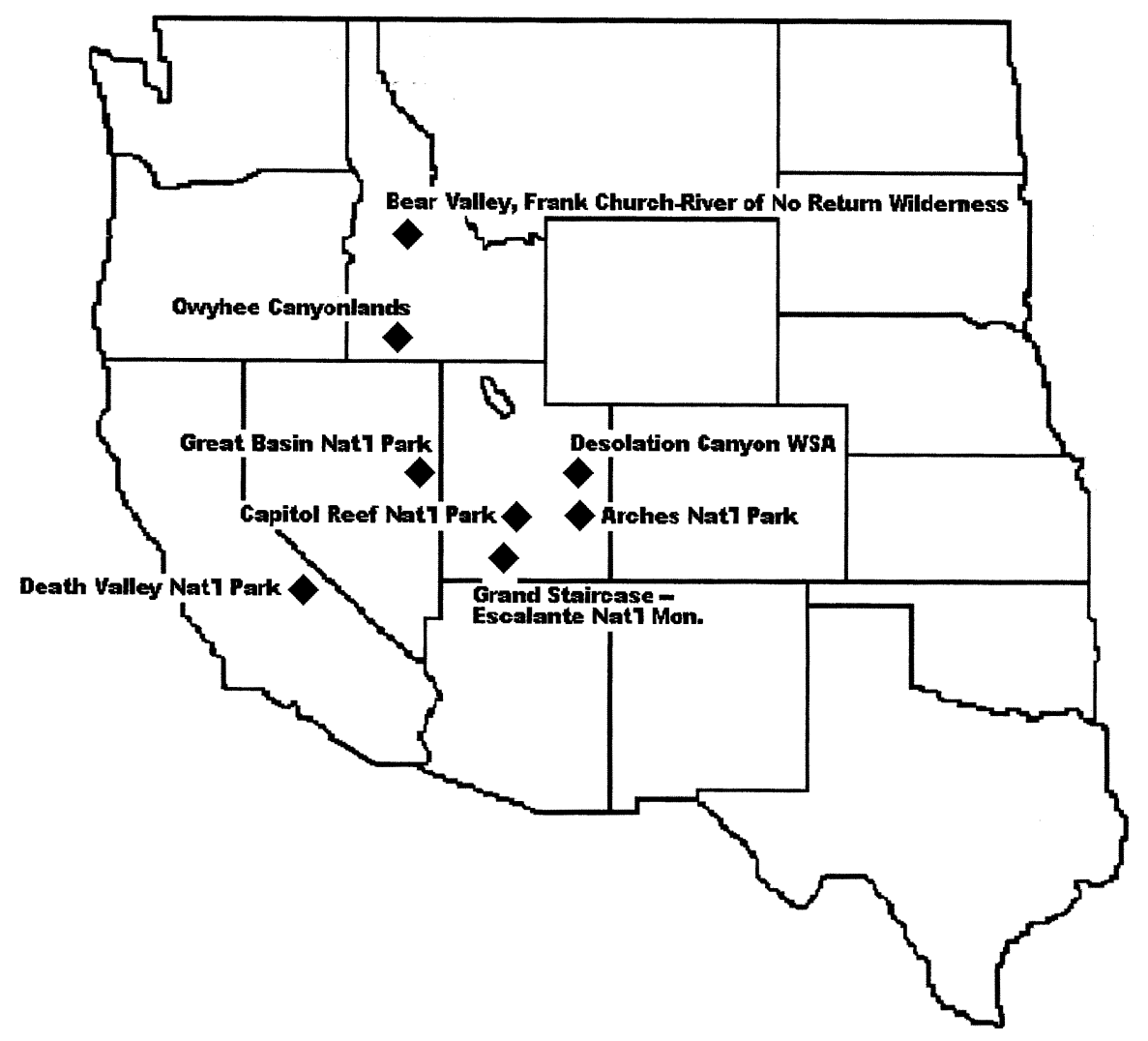


Area in exchange for compensation from a host of conservation foundations. Permits were retired on Park Service, Forest Service and Bureau of Land Management lands. The transaction was also supported by the Nevada Cattlemen's Association, the Nevada Commission on Tourism, and the U.S. Fish and Wildlife Service. A total of 2,429 AUM on 101,000 acres were retired for approximately $\$ 2.20$ per acre or $\$ 90.61$ per AUM.

Grand Staircase-Escalante National Monument, Utah - In 1998/9 the Grand Canyon Trust negotiated and raised funds to close or partially close eleven grazing allotments in the Grand Staircase-Escalante National Monument and nearby Glen Canyon National Recreation Area. Five permittees agreed to trade allotments or relinquish their permits to the BLM in exchange for fair compensation from Grand Canyon Trust. The BLM administratively retired the permits by amending the Escalante Management Framework Plan to reallocate forage to "wildlife, watershed conservation, riparian and fisheries." ${ }^{3}$ Four allotments were closed in their entirety and portions of four other allotments were also closed, removing 3,853 AUMs from nearly 100,000 acres on 132 miles of southwestern riparian canyons. Additionally, grazing reductions were achieved on three upland allotments amounting to 1,377 AUMs.

Owyhee Canyonlands, Idaho • In 1998 the U.S. Air Force sought to create a bombing range in the Juniper Draw on the East Fork of the Bruneau River in southeastern Idaho. One grazing permit had to be retired before the area could be used for training. Legislation sponsored by then-Senator Dirk Kempthorne (R-ID) authorized the Air Force to "buy out" the permit. ${ }^{4}$ In addition, the Air Force was directed to purchase replacement AUMs on an adjacent allotment from another rancher and transfer those to the displaced permittee as additional compensation for his loss. The displaced Juniper Draw permittee was compen-

${ }^{3}$ See BLM EA\# UT-049-98-43.

${ }^{4}$ P.L. 105-261 § 2907.

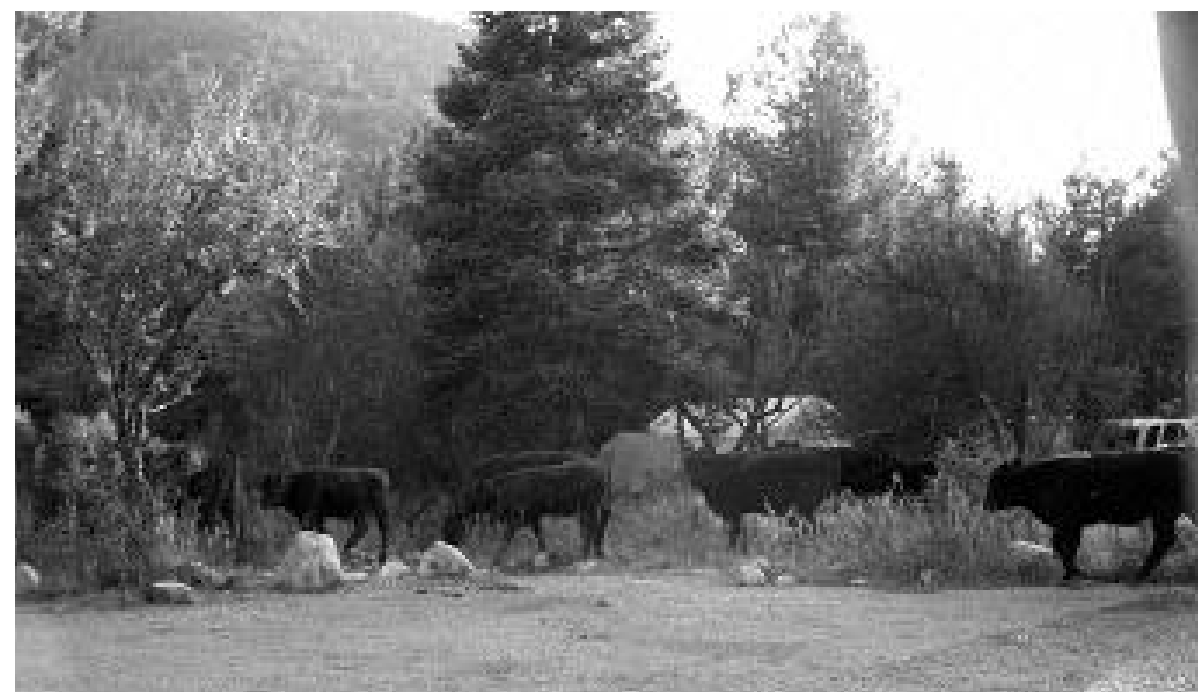

Campground, Great Basin National Park.

sated at about $\$ 110$ per AUM on 12,000 acres, while the grazer providing replacement grazing privileges received about $\$ 150$ per AUM $(\$ 340,000)$. This may be the weakest example of economically efficient, permanent permit retirement due to the unrealistically high price and the fact that the Air Force recently began leasing grazing again on the allotment it paid over $\$ 1,000,000$ to close.

Desolation Canyon WSA, Utah • Although within a wilderness study area, the Elliot Mountain, Bighorn Benches, Trail Canyon and Little Park grazing allotments in Desolation Canyon were badly degraded by domestic sheep grazing in the late 1980s. Conservationists, seeking to improve habitat for bighorn sheep in the canyon and to remove the threat of the wild sheep contracting a fatal disease carried by domestic sheep, suggested the livestock operator retire his permit for compensation. The operator agreed and was paid by the Utah Division of Wildlife with funds donated by private interests. Meanwhile, the BLM drafted a planning amendment to allocate all available forage on the allotments to wildlife and designated them the Gray Canyon Wildlife Management Area. Although the BLM is not legally required to manage the allotments as cattle free, the agency is wisely yielding to public pressure to permanently exclude livestock grazing from the area. The deal involved $\$ 30,000$ to re- move sheep from 125,000 acres, approximately $\$ 13$ per AUM.

Bear Valley, Frank Church-River of No Return Wilderness, Idaho • The Elk Creek Allotment in the Frank Church-River of No Return Wilderness includes much of the Elk Creek drainage in Idaho, a tributary to the Snake River and prime riverine habitat for federally threatened or endangered chinook salmon, steelhead, bull trout and westslope cutthroat trout. In 1998 then-Senator Dirk Kempthorne (R-ID) proposed that the Bonneville Power Administration use fish restoration funds to purchase and retire the grazing permit for the allotment to protect and restore habitat for these sensitive species. The power agency agreed to the proposal (partly in an attempt to shift the Snake River dam removal debate to salmon habitat restoration), as did the Idaho Department of Fish and Game and Shoshone-Bannock Tribes. The livestock operator volunteered to retire the permit. Although there was some concern over how BPA and the Forest Service could legally retire the permit, BPA eventually paid for the permit outright, and the Forest Service drafted a planning amendment to the forest management plan to retire the allotment. The cost was $\$ 145,000$ for 1350 AUMs on 49,000 acres.

Death Valley National Park, California - Although the California Desert Protection Act permanently 


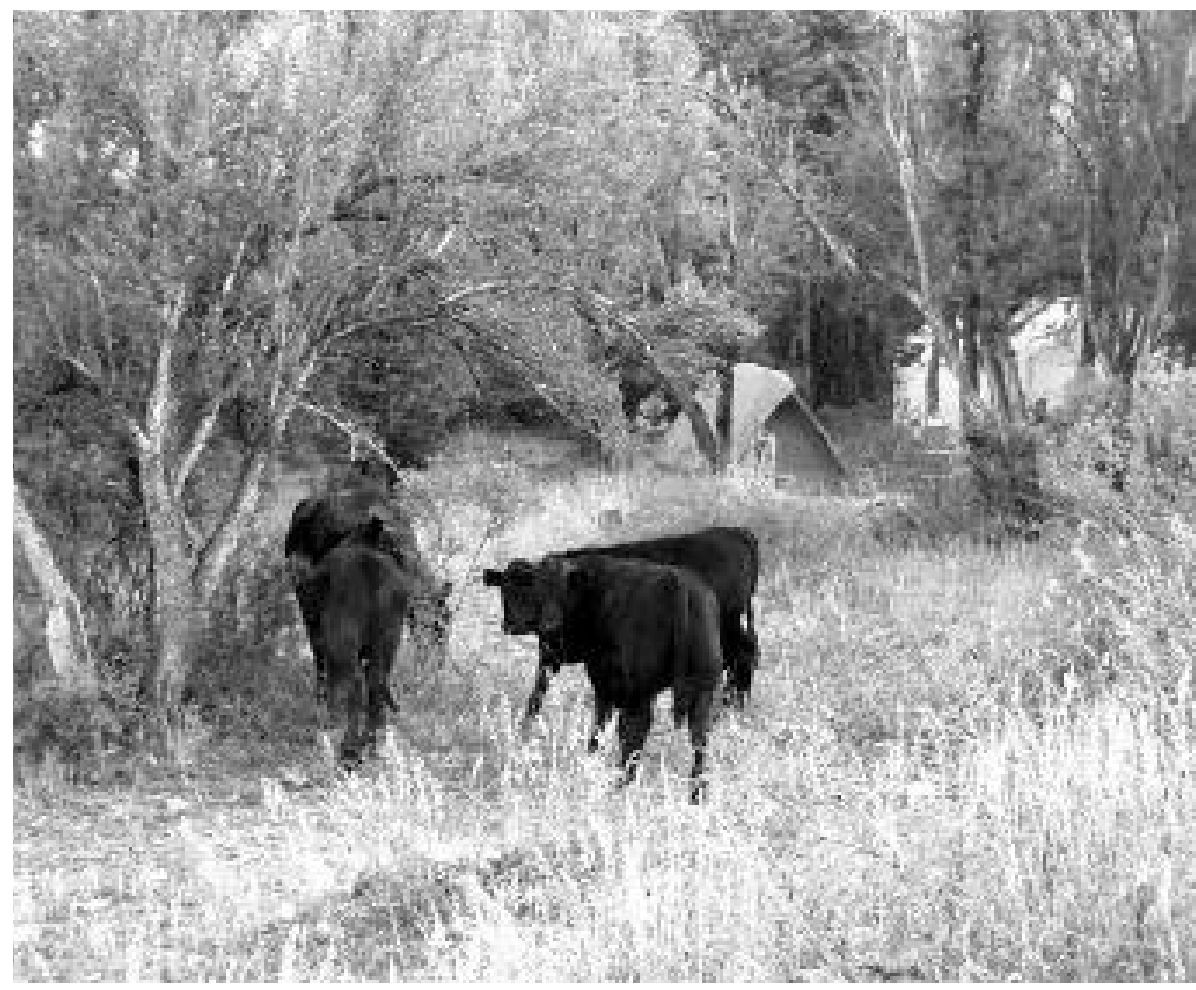

Campground, Great Basin National Park.

grandfathered livestock grazing in Death Valley National Park, ${ }^{5}$ a provision in the Draft Environmental Impact Statement/General Management Plan for the park would retire grazing permits in the same manner as was done in Great Basin National Park. ${ }^{6}$ The Park Service is using its general management authority to allow for permit retirement. The revised DEIS/Plan will be finalized in 2001.

Capitol Reef National Park, Utah - The future of livestock grazing in Capitol Reef National Park has been in contention since its establishment in 1971. Disputes over a phase-out of existing permits helped ignite the sagebrush rebellion, and resulted in federal legislation that assured continued

\footnotetext{
${ }^{5}$ P.L. 103-433 § 306(a) ("The privilege of grazing domestic livestock on lands within the park shall continue to be exercises at no more than the current level, subject to applicable laws and National Park Service regulations").

${ }^{6}$ Alternative 1: Proposed Action. GRAZING/RANGE MANAGEMENT. "The park would also work with conservation organizations to purchase grazing permits from willing sellers. Once a grazing permit was purchased and the new owners (i.e., conservation organizations) request retirement, it would be permanently retired."
}

grazing in the park for decades. Then, in 1988 the Park Service was appropriated funds (and authorized) to pay ranchers to retire their grazing permits. Seventy percent of grazing in the park was retired over the next several years. However, increases in the value of grazing permits gradually priced the Service out of the market (which was statutorily limited to a maximum payout of \$52/AUM). In 1998/9 two permits for the 11,688 acre Cathedral Allotment, the last active allotment in the northern third of the park, came on the market. Unable to meet the asking price for the Cathedral permits, the Service approached the Grand Canyon Trust about making up the difference between the price and what the Service could legally pay. The Trust agreed. With the retirement of the Cathedral permits, only two permits for grazing in the park still exist.

Arches National Park, Utah • In 1998 Congress added Lost Spring Canyon $(3,140$ acres $)$ to Arches National Park. Under BLM ownership, the entire Lost Spring Canyon system had been grazed for many years by one permittee. As Congress considered adding the canyon system to the park, the Grand Canyon Trust reached an agreement with the permittee to retire his grazing permit. Congress enacted language authored by the Grand Canyon Trust in the Lost Spring Canyon bill that gave legislative backing to the retirement deal and directed the Park Service to close the allotment as soon as the permit was relinquished. ${ }^{7}$ With all the preliminary work completed, the permittee was compensated and the permit retired the day after the legislation was signed into law. This permit retirement was the result of foresight and good working relationships between the Grand Canyon Trust, Arches National Park staff, Rep. Chris Cannon (R-UT), and the permittee.

${ }^{7} 16$ U.S.C. $272 \mathrm{a}$.

Mark Salvo is Grasslands Advocate for American Lands, an organization committed to removing domestic livestock from inappropriate public lands as quickly and efficiently as possible. He may be reached at mark@sagegrouse.org.

Andy Kerr of The Larch Company feels there is no limit to the good that can be done with other peoples' money. He agitates for livestock-free public lands and writes from Oregon's Rogue Valley. He may be reached at andykerr@mind.net. 